\title{
AL-BUKHARY INTELLECTUL GENEALOGY: TRACING THE AUTHORITY OF AN EXPERT OF HADITH AND FIQH
}

\author{
Author: Muh. Fathoni Hasyim \\ UIN Sunan Ampel Surabaya, Jl. A.Yani 117 Surabaya, Indonesi \\ e-mail: mufah.hasyim@gmail.com
}

\begin{abstract}
This article aims to reveal the authority of al-Bukhary as intellectul figures who have independence in dul scientific authority. He is often assumed as an expert of hadith only. In fact, as a collector of hadiths, he studied those hadiths deeper as a source of law which produced ijtihad products that are different compared to the predecessors. Therefore, some people argue that he is not only an expert of hadith but also a mujtahid (fiqh expert). In this context, it is interesting to explore the intellectul genealogy of al-Bukhary. The findings of this study prove that he succeeded in occupying a high position as an expert of both hadith and fiqh by interacting with many scholars from various regions. This interaction form his intellect which worthy of being called the absolute mujtahid. Al-Bukhary succeeded in exploring fiqh thoughts based on his extensive and deep mastery of hadiths. Through his ijtihad products, alBukhary had built a dynamic and authoritative tradition of Islamic intellectul treasure.
\end{abstract}

Keywords: Genealogy, al-Bukhary, Expert of hadith and fiqh

\begin{abstract}
Abstrak
Artikel ini bertujuan untuk mengungkap otoritas al-Bukhary sebagai tokoh intelektual yang memiliki independensi dalam otoritas ilmiah. Ia sering dianggap sebagai ahli hadis saja. Bahkan, sebagai pengumpul hadis, ia mempelajari hadits-hadits tersebut sebagai sumber hukum yang menghasilkan produk ijtihad yang berbeda dibandingkan dengan para pendahulunya. Oleh karena itu, beberapa orang berpendapat bahwa ia bukan hanya ahli hadits tetapi juga seorang mujtahid (ahli figh). Dalam konteks ini, menarik untuk mengeksplorasi silsilah al-Bukhary yang intelek. Temuan penelitian ini menunjukkan bahwa ia memiliki otoritas independen sebagai ahli hadits dan fiqh. Otoritas tersebut merupakan hasil interaksi dengan banyak ulama dari berbagai wilayah. Interaksi guru-murid dalam upaya kodifikasi hadis ini membentuk kecerdasannya yang layak disebut mujtahid mutlak. Al-Bukhary berhasil mengeksplorasi pemikiran fiqh berdasarkan penguasaan haditsnya yang luas dan mendalam. Melalui produk ijtihadnya, al-Bukhary telah membangun tradisi yang dinamis dan otoritatif dari khazanah intelektual Islam.

Kata Kunci: Genealogi, al-Bukhari, ahli hadits dan fikih

\section{Introduction}

In his book entitled "al-Sunnah al-

Nabawiyah Baina Abl al-Fiqh wa Abl al-

Hadits," Muḥammad al-Ghazaly once criticized the hadith observers who prematurely made legal conclusions which contradicted the opinions of Imam
\end{abstract}


Mujtahid or contrary to the other stronger hadiths and al-Qur'an because there were gaps between hadith and fiqh experts. Therefore, Muhammad al-Ghazaly invited hadith experts and fiqh experts to work together in solving contemporary socil problems.

A study on al-Bukhary is to describe a person who was able to combine his expertise in the field of hadith and figh. This is because every study on the figure of al-Bukhary always provides dimensions and findings that show his intellectual and spiritual position which is high in the dynamics of Muslim intellectauls. Therefore, there have also been many classical and contemporary Muslim historins who wrote about the figure of al-Bukhary. ${ }^{1}$ In fact, the study on al-Bukhary always contributed to photographing his intellectul work.

\footnotetext{
1 There are a number of books which mention alBukhary in one chapter and at the beginning of the book as an introduction to the edited book such as Muhammad Fu'ad 'Abd al-Baqy, who edited the book of al-Adab al-Mufrad by al-Bukhary. He included articles by Muhib al-Din al- Khatib, “ $A l$ Ta'rif bi al-Imam Muhammad ibn Isma'il al-Bukhary" as an introduction to the book to get to know the author. Instead, one chapter can be included because it is shari from the hadith of al-Jami' alSabih works of al-Bukhary such as Fath al-Bary by Ibn al-Hajar al-'Asqalany. 'Umdah al-Qary by Badr al-Din al-'Ainy, Irshad al-Sary by al-Qastalany, alKawakib al-Darary by al-Kirmany, Sharh al-Bukhary by Ibn Battal, Fath al-Bary by Ibn Rajab and many others mentions al-Bukhary biography etc.
}

Among the scientific works that have studied the figure of al-Bukhary, the one written by Hamlainy 'Abd al-Majid Hasyim, under the title al-Imam al-Bukhary Mubaddisan wa Faqiban ${ }^{2}$ has substantively provided information that he was a scholar of hadith and fiqh. This conclusion was derived from al-Bukhary thinking in the field of Islamic law. In addition, he was a hadith expert who carried out ijtihad in istinbat law in a methodological manner.

A Western intellectul namely Scott C. Lucas also conducted a study on alBukhary in his article entitled "The Legal Principles of Mubammad B Ismail al-Bukhary and Their Relationship to Classical Salafi Islam". This article reveals al-Bukhary methodology of istinbāt law. Lucas's valuble findings of al-Bukhary concludes that he was a mujtahid in his era. Therefore, he was not only a hadith expert but also a fiqh expert. ${ }^{3}$ In fact, according to Ahmad Amin, the expertise of al-

\footnotetext{
${ }^{2}$ This book was printed and published by al-Dar alQaumiyah al-T\}iba'ah wa al-Nashr in Cairo, Egypt. Middle Eastern publications often do not include the year of publication. Thus, this book does not include the year of publication.

${ }^{3}$ Scott C. Lucas, "The Legal Principle of Muhammad ibn Ismail al-Bukhary and Their Relationship to Classical Salafi Islam", in Journal of Islamic Law and Society 13, 3 Leiden: Koninklijke Brill NV, 2006. p.292
} 
Bukhary in the field of fiqh was due to his profound expertise in hadith. ${ }^{4}$

There are several reasons which make this study is interesting. First, this study traced the important figures in the formation of al-Bukhary intellectul figure as an expert of hadith and fiqh; Second, this study mapped the intellectul journey (ribla) of al-Bukhary in forming an established his expertise in hadith and figh at the same time; Third, this study focused on alBukhary authority in producing fiqh ijtihad.

This article discussed the biography and socil settings of al-Bukhary based on the above-stated context. This section briefly reveals the biography and socil condition of al-Bukhary as well as the dynamics political struggle in order to put al-Bukhary in the frame of intellectul history and to describe the response of scholars to him. In the next section, this article will describe the scientific journey of al-Bukhary where he met and talaqqi to the prominent scholars in his era. This journey describes the genealogy intellectul of al-Bukhary as a mujtahid supported by the statements of various scholars to acknowledge his scientific authority.

4Ahmad Amin, Duha al-Islam,(Cairo: Maktabah al-Nahdah al-Misriyyah, 1974), p.114.

\section{Al-Bukhary and the Intellectul Tradition of Central Asia Ulamas}

Central Asia has been a part of the Islamic world since the early 8th century. The battle of Talas $^{5}$ in $751 \mathrm{H}$ between the Abbasid army and the Tang Dynasty to rule Central Asia was the starting point of mass conversion in the region to become Islam. Central Asia is called as an area beyond the river (mawara'a al-nahar) or Transoxani. It has traces of an extraordinary Islamic civilization.

Central Asia extends from the Caspin Sea in the West to China in the East and from Afghanistan in the South to Russi in the North. This area currently consists of five independent countries: Kazakhstan, Kyrgyzstan, Tajikistan, Uzbekistan, and Turkmenistan. The total population in the Central Asia region is around 70 million people from a various ethnic group such as Kazakh, Uzbek, Tartar, Turkey, Uyghur, Kyrgyz, Tajik, Persi, Pashtun, and others.

During medieval Islam, the centers of Islamic civilization and intellectulism were not only in Mecca, Medina, Baghdad, Kufa, Damascus, or

\footnotetext{
${ }^{5}$ Talas is the name of a battle field located in Kyrgyzstan. The battle of Talas is a border conflict between the Abbasid from Baghdad and Tang dynasty from China in order to compete for power in the Syr Darya. This battle took place in May to September 751 with the victory over the Abbasid.
} 
Cairo but also in Samarkand, Bukhara, and Urgench. Those Central Asia countries became centers of study, art, and Islamic culture. This is evident that Central Asia has given birth to important figures in the development of Islamic science such as al-Bukhary, al-Hakim alNaisabury, Abu al-Hakim al-Tirmizy, Abu Hafs Umar al-Nasafy, Abu al-Lais alSamarqandy, Ibn Sina, al-Khawarizmy, alZamakhshary, Muslim bin Hajjaj alQushairy, Abu Bakr bin Musa al-Baihaqy, and Bahauddin al-Naqshabandy. ${ }^{6}$

From the above stated Central Asia scholars, it shows that those scholars became the references in various disciplines, hadith experts, logicins, mathematicins, Sufism or Tariqa experts and others. This is because Central Asia has become the center of civilization in the midle ages. Many prominent scholars born from Southeast Asi are proof that Islamic civilization has achieved its glory.

The tradition of Central Asin Muslim intellectuls was ribla. Al-Bukhary had made many scientific journeys (ribla) in order to codify hadiths. Other hadith scholars such as al-Tirmizy also did the same. Al-Tirmizy undertook a scientific

${ }^{6}$ Shirin Akiner, "Islam, the State and Ethnicity in Central Asi in Historical Perspective," Journal of Religion, State \& Society, Vol. 24, No. 2/3 (1996), p. 94 journey around $235 \mathrm{H}$ after studying with the teachers in his country. Nur al-Din 'Itr wrote a statement that al-Tirmizy had visited Khurasan, Naysabur, Iraq, and Hijaz. ${ }^{7}$

In this context, it can be said that the Central Asia scholars have in common intellectul traditions with Nusantara ulama (Ulama of the archipelago). This similarity can be seen from the scientific activities carried out by the ulama of archipelago in order to study religion in Hijaz. Many leaders of archipelago scholars did scientific research in Hijaz. ${ }^{8}$ Thus, it proves the relationship between Haramayn and the Archipelago. Likewise, Central Asia scholars in medieval Islam also intersected with prominent scholars in Hijaz.

\footnotetext{
${ }^{7}$ Nur al-Din 'Itr, al-Imam al-Tirmizy wa alMuwazanah Bain Jami'ih wa Baina al-Sabibain (Cairo: Matba'ah Lajnah al-Ta'lif wa al-Tarjamah wa alNashar, 1970), p.11

8 There are Shekh Khatib al-Sambasy, Shekh Arsyad al-Banjary and Shekh Nafi' al-Banjary in Kalimantan. There are Shekh Ismail alMinangkabawy, Shekh Abdusshommad alFalimbany, and Shekh Ahmad Khatib AlMinangkabawy, Shaikh Abdul Wahab Sandenreng Daeng Bunga Bugis in Sumatera. There are Shekh Nawawi al-Bantany, Sheikh Agung Asnawi bin Sheikh Abdurahman Caringin al-Bantany, Shekh Mahfudz al-Tirmasy, Shekh Abdul Karim alBantany in Java. There is Shekh Abdul Gani Bima in Nusa Tenggara Barat. In the 19th century, they were in the Masjid al- Haram Mecca to be the archipelago ulama.
} 


\section{Al-Bukhary and Social Setting}

Al-Bukhary's full name is Abu 'Abd Allah Muhammad ibn Isma'il ibn Ibrahim ibn Mugirah al-Ju'fy ibn Bardizbah al-Bukhary. ${ }^{9}$ Al-Bukhary was born in Bukhara on the 13 Shawwal 194 ${ }^{10}$ coincided with July $12,810 \mathrm{M}$ after Friday prayer. He died on Saturday, ahead of the isya' prayer on the eve of Eid al-Fitr 1 Shawwal $256 \mathrm{H}$ coincided with 31 August 870 M. Therefore, al-Bukhary lived for 62 years minus 13 days according to the calculation of the Islamic calendar. ${ }^{11}$

Al-Bukhary was born to a science lovers family. His father named Ismail ibn Ibrahim is a great scholar of hadith experts. The hadiths that were mastered were obtained from Hammad ibn Zaid, Imam Malik ibn Anas (w.179/798), Safih ibn al-Mubarak, Abi Mu'awiyah and other people. The hadith collected by him were narrated by Iraqis and the father of alBukharya. This was recorded by ibn Hibban in Kitab al-Siqat, the collection of

9Ahmad ibn 'Aly ibn Hajar al-'Asqalany, Hady alSary (Cairo: Dar al-Diya li al-Turas, t.th.), p. 501.

${ }^{10}$ According to al-Mustamir ibn 'Atiq, the data on the birth was obtained from al-Bukhary in the form of a note written by his father, Isma'il. See al'Asqalany, Hady al-Sary, p. 501. This show the diligence of al-Bukhary father to write and to keep records.

${ }^{11}$ Ahmad ibn 'Aly al-Khatib al-Bagdady, Tarikh Bagdad aw Madinah al-Salam, volume II (Cairo: alKhaniji, 1931), juz II, p. 6. See also:Encyclopaedi Britannica (Chicago: Wilham Benton,1965), p. 382. biographies of trusted hadith experts. AlBukharyincluded his father's name in the book of al-Tarikh al-Kabir, the biography of the well-known hadith narrators. Biographers wrote that the father of alBukharywas a science lover, an expert in religion/piety and be wara. ${ }^{12}$ The mother of al-Bukhary was good at teaching the Qur'an. Therefore, since his childhood, alBukhary learned to read Qur'an to his mother before studying in kuttab-kuttab. ${ }^{13}$

The above description shows that al-Bukhary was born from a family that was very concerned about science and devout in religion. At that time, the knowledge which became the focus was Qur'an and hadith. Kuttab-kuttab and mosques concentrated education on these two disciplines and supporting sciences such as writing, reading, and grammar. Therefore, it is not surprising that alBukhary devoted his attention to science, especilly the science of hadith. He became a zubud and wara'in a family environment.

Al-Bukhary lived in two periods of 'Abbasid rule, at the end of the first period and the beginning of the second

\footnotetext{
12‘Abd al-Wahhab ibn Taqy al-Din al-Subky, Tabaqat al-Shafi iyyah al-Kubra, juz II (Egypt: alHasiniyyah, t.th.), p. 3

${ }^{13}$ Muhammad Muhammad Abu Shuhbah, Fy Ribab al-Sunnah, Al kutub al-Sittah al-Sibhah, Cairo:Majma“ al-Bubus al-Islamiyyah, 1969. p. 44
} 
period. ${ }^{14}$ During his life $(194-256 \mathrm{H})$, there have been ten times changes of leadership (Caliph) started from Abu Musa Muhammad al-Amin (w. $193 \mathrm{H}$ ) to Abu al-'Abbas Ahmad al-Mu'tamid (w. 256 $\mathrm{H})^{15}$.

This relatively rapid change of leadership indicates political instability. In those days, there were power struggles between siblings such as from Caliph alAmin to Caliph al-Ma'mun (w. 218 H) and from Caliph Mutawakkil to Caliph alMuntasir (w. $247 \mathrm{H}$ ). There were also coups done by the child on his father and others.

The tension and conflict did not only occur among political and military practitioners but also among intellectuls. The mujtahids really apprecite differences of opinion. However, their students who were fanatical about the views of the mujtahid admired and followed (taqlid) trigger a conflict that sometimes involves the scholars or intellectuls.

\footnotetext{
14 Historins devide the reign of 'Abbasid into 3 periods with certain characteristics. In the first period $(132-232 \mathrm{H})$, power was in the hands of the khalifah. In the second period $(232-590 \mathrm{H})$, political power moved from khalifah to Turkish, Buwaih, and Saljuq ethnic groups. During the third period $(590-565 \mathrm{H})$, the power returned to the caliph but was limited to Baghdad and the surrounding area. See A. Syalabi, Sejarah dan Kebudayan Islam, volume III (Jakarta: Pustaka alHusna, 1993), pp. 2-3

${ }^{15} \mathrm{Jalal}$ al-Din al-Suyuti, Tarikh al-Khulafa' (Beirut: Dar al-Fikr, 1974), pp. 276-336
}

This internal intellectul conflict such as between Hijaz and Kufa school of law in figh actully happened at the end of the second century of the Hijrah. There was also intellectul conflict between Mu'tazilah school of law, Murji'ah school of law, and Sunnah experts in theology. At the beginning of the third century of Hijrah, the disagreement regarding figh and kalam increased. In this period, the scholars of hadith faced fanatic groups of fiqh and kalam school of laws, especilly the Mu'tazilah who were very hostile towards the hadith scholars.

The disagreement between ulama of kalam science and the scholars of hadith had actully occurred since the second century of Hijrah. However, during that time, the authorities did not intervene in the conflict. Thus, the tensions were only limited to conflicts between groups of thoughts. In the early third century of the hijrah, the government was ruled by Caliph alMa'mun (w.218 /833), one of the leaders who were very concerned about the intellectul activity. The government involved in intellectul activities. AlMa'mun (w. $218 \mathrm{H}$ ) gave patronage to the Mu'tazilites and made them an officil state school of law. As a result, Mu'tazilite ideas were legitimized to be forced on society. 
This ended with the killing of the ulamas and those who did not in the same thought as Mu'tazilah school of law. This event is known as mibnab. ${ }^{16}$ All government officils ranging from ministers, warlords, as well as judges were tested for their faith in the oneness of Allah, especilly related to the characteristics of ma'ani, such as the nature of kalam which deals with the conquest of the Qur'an. Officils who have different beliefs with Mu'tailah were dismissed. Likewise, the scholar of hadith faced a very severe test. The scholars of hadith who did not acknowledge the conquest of the Qur'an were put in prison and tortured including Ahmad ibn Hanbal (w. $241 \mathrm{H}$ ), Muhammad ibn Nuh, Ahmad ibn Nasr al-Khuza'i, and Abu Ya'qub alBuwaity (w. $231 \mathrm{H}){ }^{17}$

\footnotetext{
${ }^{16}$ Mibnah was triggered by Mu'tazilah's opinion about the conquest (creation) of Qur'an. In the Mu'tazilah view, the Qur'an is the word of Allah. Kalam Allah is a creature (created). Therefore, the Qur'an is new, not qadim.If the Qur'an is qadim, there are many qadim beside Allah. See Qadi alQudat 'Abd al-Jabbar Ahmad, Sharh Usual alKhamsah, Tahqiq 'Abd al-Karim 'Usman (Cairo: alIstiqlal al-Kubra 1384/1965), pp. 529-563. The Mayor of Baghdad, al-Ma'muan, ordered an examination to the judges (qudat) to accept the concept of the conquest of the Qur'an and instruct the judges not to accept the testimony (shahadab) of people who do not accept this concept.
}

${ }^{17}$ As Ahmad ibn Hanbal, al-Buwaitya was also the greatest student of al-Shafi'y ain Egypt. He was a debater, expert on worship, Zahid, faqih and the author of al-Mabsuat. For his role, Shafi'ya school of law was widespread outside Iraq and Egypt. He was one of the figures who defended the faith of the Sunnah expert. He was arrested, thrown into a prison in Baghdad, handcuffed, and neck shackled,
This unfavorable condition for the scholars of hadith continued during the Caliph al-Mu'tasim (w. $227 \mathrm{H}$ ) and alWasiq (w. $232 \mathrm{H}$ ). It was only during the reign of Caliph al-Mutawakkil (w. $247 \mathrm{H}$ ) that hadith scholars could breathe a sigh of relief because the Caliph had concern for hadith experts, revoked the mihnah order, and released the prisoners who were imprisoned. In addition, the Caliph forbade discussing the problem and the complicated and sensitive problems in theology. This is the behavior of the Salaf scholars, the manhaj of Imam Ahmad ibn Hanbal (w. $241 \mathrm{H}$ ) and Imam al-Bukhary a. ${ }^{18}$

Al-Bukharyreceived a tremendous welcome when visiting Naisabur. The regional head, the ulama, the Naisabur residents as well as Muhamad ibn Yahya al-Zuhlya (the great scholar of hadith resided in Naisabur, the teacher of Imam al- Bukhary and Imam Muslim) welcomed the arrival of al-Bukhary aoutside the city, as far as two or three marbalah $( \pm 100 \mathrm{~km})$. Majlis ta'lim (Islamic forum) held by alBukharywas visited by many people. Naisabur residents crowded into the majlis

and finally died in prison under such circumstances in Rajab $231 \mathrm{H}$. See Taqiy al-Din Aby Bakr ibn Ahmad ibn Qady Shuhbah, Tabaqat al-Fuqaha' al-Shafi'iyah, juz I (Cairo: Maktabah alS | aqafah al-Diniyyah, t.th.), pp. 38-39.

${ }^{18} \mathrm{Al}-$ Suyuty, Tarikh al-Khulafa' $a$, p. 320. 
ta'lim of al-Bukhary. Thus, majlis ta'lim of the other ulamas were deserted including the majlis ta'lim of Muhammad ibn Yahya al-Zuhlya. However, soon al-Bukharygot slander from envious people. ${ }^{19}$ They accused him of having the opinion that the Qur'an was a creature. The teacher he respected, Muhammad ibn Yahya alZuhlay was angry and issued an ultimatum to him:

'Who ever believes that al-Qur'an is a creature, then he is an expert in heresy. He may not be invited to talk and his majlis cannot be visited. Who ever still visits his majlis should be expelled." After the ultimatum, people began to move away from al-Bukharyexcept Imam Muslim and Ahmad ibn Salamah. Al-Zuhly asaid again "Remember, anyone who believes that al-Qur'an is a creature may not attend our majlis." These words addressed to Imam Muslim because he still often came to visit al- Bukhary a. Hearing these words, Muslim stood up and left the majlis witnessed by other students. Then, he sent all the notes of lessons he had learned from al-Zuhly to being transported with a camel.

Actully, al-Bukhary was not as alleged. Once, there was a man who wanted to clarify the accusation. During a majlis, a man stood and asked al-Bukhary: "What do you think of al-Qur'an, is it a

${ }^{19}$ According to Ibn Hajar, only two or three days from the presence of al-Bukharya in Naisabur, his majlis ta'lim had begun to be abandoned by people. Al-'Asqalanya, Hady al-Sary, volume I, p. 515 creature or not?" al-Bukhary turned away from that person and did not want to answer even though the question was asked three times. However, the person continued to urge. Then, he replied, "alQur'an is the word of Allah. It is not a creature while human actions are beings mibnah is bid'ab". According to the expert of tahqiq and salaf scholars, what is meant by human action is to read or pronounce it right. The Majlis became chaotic. They had different perceptions. Then, things did not turn out well. They became confused instead. Finally, they left the majlis of al-Bukharyone by one. ${ }^{20}$

The opinion expressed by alBukharydistinguishes between the reading and read. ${ }^{21}$ However, people could not understand well. They had their own perceptions. On another occasion, alBukharyexplained that: "Human actions such as beings, motion, sound, deeds, and writings are creatures while al-Qur'an which is written in manuscripts and preserved in the heart is Allah's word, not a creature."Another narration mentioned that al-Bukhary once said: "Faith is words

\footnotetext{
${ }^{20}$ Abu Shuhbah, Fy Rihab al-Sunnah, p. 45 and 47. ${ }^{21}$ Hashim gave an example. For example, someone said that a person is a good or bad qira'ah. This does not mean that the person is good or bad. Qur'an is the word of Allah which isqadim, while reciting or writing the letters of the Qur;'an is a human act. Humans are creatures. See Hashim, alImam al-Bukhary, p. 69.
} 
and deeds. It can increase and decrease. Al-Qur'an is the word of Allah, not creature. The companions of Rasulullah, Abu Bakar, 'Umar, 'Us \man and 'Alya, were holding on to this faith. 'I live, I die, and am resurrected in the hereafter,' insha Allah", and on another occasion, he said: "Whoever accuses me of arguing that alQur'an is a creature, he is a lir". ${ }^{22}$

The explanation made by alBukhary was so explicit, clear, and slightly emotional. However, it could not clarify the sitution because the slander had spread throughout Naisabur. Finally, alZuhly was at the peak of his anger. AlBukhary was expelled from his country. To allevite slander, al-Bukharychose to leave the country even though as a hadith expert, he was consistent with the views of the salaf and tahqiq experts. The statements made in the context of clarification show that theological doctrine he holds is on the contrary to Mu'tazilah theology. His theological doctrine was exactly the same as the view of sunnah or hadith experts. However, slander was the main factor causing the dispute between him and his teacher. Thus, he left the country.

In an effort to clear his name from the slander, al-Bukhary wrote a book

22Al-'Asqalany, Hady al-Sary, pp.575-576. entitled "Khalq Af'al al-Tbad". This book contains his views about the divinity of the Qur'an and the renewal of human actions. Moreover, he visited Bagdad to meet Ahmad ibn Hanbal, a prominent ulama who was known to be most consistent in maintaining the faith of $A b l$ al-Sunnah wa al-Jama'ah, to discuss his views on al-Qur'an.

Al-Bukhary said to Ahmad ibn Hanbal; "I am is a person who is being slandered. Actully, I do not want to say it to you, but I would better say to you my opinions about al-Qur'an. If you do not agree, reject it." Al-Bukhary said: "alQur'an is the word of Allah from its beginning to the end. Al-Qur'an is not a creature. Whoever says that Qur'an is a creature or that there is something from it that is a creature, then he is an infidel. Anyone guesses that words in the Qur'an are a creature belongs to the people of Jabmiyyah and infidel." Ahmad said "Yes". ${ }^{23}$

The above dilog shows that all opinions of al-Bukharywere justified by Ahmad. They were not rejected or denied and in accordance with the view of Ahmad ibn Hanbal, the leading hadith

\footnotetext{
${ }^{23}$ Ibn Aby Ya'la, "Tabaqat al-Hanabilah", AlMaktabah al-Shamilah, Edition II, Collection Number 46 Tarajim wa al-Tabaqata, juz I, p.110
} 
expert. This shows that the opinion of alBukharydoes not conflict with the aql of Abl al-Sunnah wa al-Jama'ah. However, all efforts made by al-Bukhary to clarify his name from the slander did not work out and was in vain. He remained isolated from his people and moved away from his residence. It is ironic that he was hailed, greeted by thousands of people standing in a row on the protocol roads, but when he left there was no one to deliver him.

These events indicate political instability in al-Bukhary's lifetime. Conflicts between intellectuls and rulers with hadith experts still haunt the population. The event of mibnah was still in effect as a tool to discredit scholars. AlBukhary at dusk became the victim of the political instability of 'Abbasid government. Al-Bukhary was isolated from the community and lived impoverished.

\section{Intellectul Genealogy of Imam Al-}

\section{Bukhary}

Along with the development of Islamic education at that time, after taking his non-formal education in his family environment and his mother as his main educator, al-Bukhary entered a basic formal education institution called
$K_{u t t a b^{24}}$ when he was $10 .{ }^{25}$ The materils of kuttab education were writing, reading, and memorizing Qur'an and hadith.

Since he was in kuttab, Al-Bukhary had shown great attention to hadith studies compared to other disciplines. This condition is an early indication that al-Bukharyinherited his father's talent and expertise in hadith. Therefore, at a relatively very young age, he had memorized more than 70,000 hadiths. Moreover, he memorized most of the biographies of the companions and tabiin who narrated the hadiths that had been memorized (data on birth, death, residence, and so on). ${ }^{26}$

After completing his education in Kuttab, al-Bukhary continued his study to specil majlis held by scholars who had extensive knowledge, especilly in the field of hadith. For example, the majlis held of al-Dakhily, Abu Zubair and many others. After al-Bukhary memorized the book written by Ibn al-Mubarak at the age of 16, he was invited to perform the pilgrimage by his mother together with his

\footnotetext{
${ }^{24}$ Kuttab or Maktab comes from the word kataba which means writing or place of writing. Therefore,kuttab is a place to learn to write. The term kuttab known to pre-Islamic Arabs and before kuttab was known in the early of Islam. As a basic education institution, mainly it taught writing and reading. Ahmad Syalabi, A History of Muslim Education (Beirut: Dar al-Kasysyaf, 1954), p.16

${ }^{25}$ Al-Bagdady, Tarikh Bagdad, p.6.

${ }^{26} \mathrm{Al}-$ 'Asqalany, Hady al-Sary, p. 507.
} 
brother, Ahmad. However, after carrying out the pilgrimage, al-Bukhary did not return to his hometown (Bukhara). Due to his high concern for science, he chose to stay in Mecca. At that time, Mecca was an important center of knowledge in the Hijaz. $^{27}$ In Mecca, al-Bukhary attended some majlis of knowledge, especilly those held by prominent scholars. Al-Bukhary found what was sought and was able to satisfy himself from his curiosity of knowledge.

Majlis is an advanced education. For students who have completed elementary education in kuttab-kuttab, they can choose between stopping and proceeding to advanced education cared for by a specil teacher or attending halaqah in mosques guided by scholars who have wider insight. Both majlis and halaqah are usully held in mosques. ${ }^{28}$ This is what is meant by the majlis education institution. The description of Majlis and mosque education have the same teaching method, imla' (dictation). After the materil is dictated, the teacher explains the materil and sometimes gives an opportunity for dilogue and discussion. ${ }^{29}$

${ }^{27}$ Al-Subky, Tabaqat, p.5.

${ }^{28}$ Bayard Dogde, Muslim Education in Medieval Times (Washington D.C.: The Middle East Institute, 1962), pp.7- 8 .

${ }^{29}$ Mehdi Nakosteen, History of Islamic origins of Western education. A.D. 800-1350 with Introduction to
There had been several kinds of majlis during al-Bukharya's life such as majlis hadis, majlis tadrias, majlis munaazarah, majlis muzakarah, majlis shu'ara', majlis adab, majlis fatwa, majlis nazar and so on. The majlis hadith was divided into two types; occasional (periodic) and permanent. Periodic majlis was held twice or only once a year with a relatively limited number of hadiths. In this majlis, the teachers were usully scholars who master several scientific disciplines other than hadith. Meanwhile, permanent majlis needed a longer time, around 20 to 30 years. The teachers were an expert on the field he taught. ${ }^{30} \mathrm{Al}$-Bukhary had attended one majlis to another majlis of some prominent scholars in his homeland for about six years before he left to Meccat the age of 16.

In Hijaz, al-Bukharystudied with the students and friends of al-Shafi'y who were experts in fiqh an hadith. Al-Bukhary studied at al-Humaidy, a great mufti who was an expert of fiqh and hadith, at the age of $18 .^{31}$ In Mecca, he also wrote fiqh book for the first time entitled Qadaya al-

Medieval Muslim Education (Boulder: University of Colorado press, 1964), p. 46.

${ }^{30}$ Munir al-Din Ahmed, Muslim Education in The Scholars Socil Status (Zurich: Verlag Der Islam, 1968), pp. 56-57.

${ }^{31}$ Shams al-Din al-Zahaby "Siyar A'lam alNubala", al-Makatabah al-Shamilah, edition III, Majmu'ah No. 46 Tarajim wa al-Tabaqat, No. 132, p. 400. 
Sahabah wa al-Tabi in at a relatively young age, 18 years old. In the same year, he also compiled the book al-Tarikh al-Kabir (the history of hadith narrators). He wrote and compiled near the tomb of Rasul Allah at night when moonlighted. ${ }^{32}$

Therefore, it is natural that alBukhary composed many books of figh such as Raf al-Yadaini fay al-Salah, Khair alKalam al-Qira'ah Khalfa al-Imam and others because his teachers were experts of figh. In fact, his first teacher while he was still living in Bukhara was an expert in fiqh. ${ }^{33}$ Moreover, the conditions of the times were conducive to writing in fiqh because the tendency of thought at that time was figh thinking in addition to hadith. However, al-Bukhary adid not only compile the book of fiqh but also composed the hadith and biography of the narrators to provide a solid foundation for the figh thinking.

In an effort to achieve his noble goals, al-Bukhary had done riblab to various countries. Almost all Islamic countries (regions which were the rule of Bagdad at that time) had been visited by him. At that time, Bagdad was the capital of the country and intellectul center where

${ }^{32} \mathrm{Al}-$ Subky, Taabaqat, pp. 2-5.

${ }^{33}$ Leksikon Islam (Jakarta: Pustaka Azet Compilation Team, 1988), pp. 101-102. However, the lexicon did not mention the name of the first teacher of al-Bukharya who is an expert in fiqh. the scholars gathered. In that country, he often visited Ahmad ibn Hanbal (w. 241/855) who was an expert of fiqh and hadith. Ahmad ibn Hanbal often invited al-Bukhary to live in the Bagdad and regretted it because al-Bukhary asettled in Khurasan. According to al-Bukhary, he had visited Bagdad eight times. Every time he visited Bagdad, he met Ahmad ibn Hanbal. $^{34}$

His journey to various countries had brought al-Bukhary together with teachers who had high scientific qulity and can be trusted. In a narration, he said: "I wrote the hadith that I received from 1,080." Among his teachers were "Ali ibn al-Madainy (w. 234/848), Ahmad ibn Hanbal (w. 241/855), Yahya ibn Ma'in (w. 233/847) Muhammad ibn Yusuf alBaikindy (w. $218 \mathrm{H}$ ) and Ishaq ibn Rahawaih (w. $237 \mathrm{H}$ ). Teachers narrated in his book entitled al-Jami al-sabih were 289 teachers. $^{35}$

Every time al-Bukhary visited a city, he always used it to study with the ulama in that city. The followings are cities that had been visited by al-Bukhary and the names of teachers he studied with:

\footnotetext{
${ }^{34}$ Al-Bagdady, Tarikh Bagdad, p. 22.

${ }^{35}$ Muhib al-Din al-Khatib, al-Ta'rif bi al-Imam Mubammad ibn Ismail al-Bukhary in al-Adab alMufrad, (takhrij) Muhammad Fu'ad 'Abd al-Baqy (Beirut: Dar al-Basha'ir al-Islamiyyah, 1989), pp.7-8
} 
a. In Bukhara and its surroundings, he studied with Muhammad ibn Salam alBaikandy (w. 225 H), Muhammad ibn Yusuf al-Baikandy (w. 218 H), 'Abd Allah ibn Muhammad al-Musnady (w. $229 \mathrm{H}$ ), Ibrahim ibn al-Ash'as and several other scholars.

b. In Balakh, he had studied with alHafiz Makky ibn Ibrahim al-Balakhy (w. $215 \mathrm{H}$ ), Yahya ibn Bishr al-Zahid, Qutaibah and others.

c. In Marwa, he had studied with Abu'Abd al-Rahman 'Ali ibn al-Hasan ibn Shaqiq, 'Abdan, Sadaqah ibn alFadal and a number of other scholars.

d. In Mecca, he studied with teachers and his qari", namely Abi 'Abd Allah ibn Yazid al-Muqri' (120-213 H), Khilad ibn Yahya, Hasan ibn Hasan al-Basri, Abi al-Walid Ahmad ibn Muhammad al-Arzaqy and 'Abd Allah ibn al-Zubair ibn 'Isa al-Humaidy, and others.

e. In Medina, he studied with 'Abd al'Aziz al-Uwaisy, Ayyub ibn Sulaiman ibn Bilal, Ismacil ibn Abya Uwais, Matraf ibn 'Abd Allah and others.

f. In Bagdad, he studied with Shuraih ibn al-Nu'man, 'Affan ibn Muslim alBasri (131-220H) Muhammad ibn 'Isa ibn al-Tabba', Muhammad ibn Sabiq and other scholars.

g. In Basrah, he studied with Abi 'Asim al-Nubail, Amr ibn 'Asim al-Qaisy (w. $213 \mathrm{H}$ ), Muhammad ibn 'Abd Allah ibn al-Musanna al-Ansary (118-215 H), Badal ibn al-Muhabbar, Muhammad ibn 'Abd Allah al-Ansary, 'Abd al-Rahman ibn Hammad alSha'isy Sahib ibn 'Aun, and others.

h. In Kufa,he studied with 'Ubaid Allah ibn Musa al-'Abbasi (w. 213 H), Abi $\mathrm{Na}$ im, Khalid ibn Mukhlad, Talaq ibn Ginam, Khalid ibn Yazid, Hasan ibn 'Atiyyah, Khilad ibn Yahya, Qabisah, Muhammad ibn 'Ar'arah, Hajjaj ibn Minhal, Badal ibn al-Mihbar, 'Abd Allah ibn al-Raja' and others.

i. In Naisabur, he studied with Yahya ibn Yahya, Bishr ibn al-Hakam, Ishaq and others.

j. In Rayy, he studied with Ibrahim ibn Musa al-Hafiz and others.

k. In Hims, he studied with Abya alYaman al-Hakam ibn Nafi‘ al-Bahrany (138-221 H) and others.

1. In Damascus (Sham), he studied with Abya Mushhar 'Abd al-Akla ibn Mashar al-Gassany (140-218 H). He also studied with Abu al-Yaman, Adam ibn Aby Iyas, 'Aly ibn 'Iyasy, 
Bishr ibn Shu'aib, Aby al-Mugirah 'Abd al-Quddus, Ahmad ibn Khalid al-Wahby, Muhammad ibn Yusuf alFirbary and others.

m. In 'Asqalan, he studied with Adam ibn Iyas $(132-220 \mathrm{H})$.

n. In Egypt, he studied with Sacid ibn Abya Maryam, Ahmad ibn Ishkab, 'Abd Allah ibn Yusuf, Asbag and others.

o. In Palestine, he studied with Muhammad ibn Yusuf ibn Waqid alFarabi Maula Bani Dabbah (w. 212 H) and others. ${ }^{36}$

There were so many teachers of alBukhary. Thus, it is difficult to sort out between the hadith experts and figh expert because many ulamas mastered various scientific disciplines at that time, for example, al-Humaidy (w. 219 H), alBukhary teacher in fiqh. He was also an expert in hadith. He compiled a quite popular book of hadith entitled Musnad alHumaidy. Al-Bukhary anarrated several hadiths from him. Moreover, the first hadith included in the revelation chapter of al-Jami al-Sabih is the hadith which he transmitted from al-Humaidy. ${ }^{37} \mathrm{Ibn}$ Hajar

${ }^{36} \mathrm{Al}-Z a h a b y$, Siyar, pp. 394-395.

${ }^{37}$ Ahmad Ibn 'Aly aIbn Hajar al-'Asqalanya, Fath al-Bary, volume I (Cairo: Dar al-Diya li al-Turas, 1988), p.15. See also Ibn Qadi Shuhbah, Tabaqat al- mentioned al-Humaidya in Fath al-Bari sharah, the book of al-Jami' al-Sabih, for 256 times. Likewise, Husain al-Karabishi (w. $248 \mathrm{H}$ ), Abu Saur (w. $246 \mathrm{H}$ ) and alZa'farany were friends of al-Shafi'y ain fiqh and hadith, especilly al-Za'farany. Many of his hadiths were transmitted by many scholars of hadith who study with them such as al-Bukhary, Abu Dawud, Turmuzy, Nasa'y, Ibn Majah and others. The four Sunny aschool of law Imams, Abu Hanifah, Malik ibn Anas, al-Shafi'y and Ahmad ibn Hanbal was also the hadith expert who transmitted the Prophet's hadith to his students and had the book of hadith which was on their name.

Al-Hafiz Ibn Hajar classified alBukhary teachers not based on domicile or specilty, but based on life span or proximity to tabiin. The result of this classification created five tabaqat as follows: First, al-Bukhary teachers who received hadith from tabiin, such as Muhammad ibn 'Abd Allah al-Ansary who got the hadith from Humaid, Makky ibn Ibrahim who got the hadith from Yazid ibn Aby 'Ubaid, Aby 'Asim al-Nubail who narrated the hadith from Yazid ibn Aby 'Ubaid, 'Ubaidillah ibn Musa who narrated the hadith from Ismacil ibn Aby Khalid,

Fuqaha al-Shafi'iyah, juz I, al-Maktabah al-Shamilah, Edition II, pp. 2-5. 
Aby $\mathrm{Nu}^{\prime}$ aim who narrated hadith from alA'mash, Khilad ibn Yahya who narrated hadith from 'Isa ibn Tahman, as well as 'Aly ibn 'Iyasy and 'Isam ibn Khalid who both narrated hadith from Hariz ibn 'Usman. All of their teachers were tabiin.

Second, the teachers of al-Bukhary lived during the first generation of tabaqat. However, they did not hear or did not narrate the hadith from siqab tabiin such as Adam ibn Iyas, Abi Mashar 'Abd al-A'la ibn Mashar, Sacid ibn Abya Maryam, Ayyub ibn Sulaiman ibn Bilal and others.

Third, al-Bukhary's teachers had never met tabiin. However, they narrate the hadith from the great tabi' al-Tabi'in such as Sulaiman ibn Harb, Qutaibah ibn Sa'id, Nu'aim ibn Hammad, 'Alya ibn alMadainy (w. $234 \mathrm{H}$ ), Yahya ibn Ma'in (w. $233 \mathrm{H}$ ), Ahmad ibn Hanbal (w. $241 \mathrm{H}$ ), Ishaq ibn Rahawaih, Abu Bakar and'Usman sons of Aby Shaibah and others.

Fourth, al-Bukhary seniors in searching for hadith such as Muhammad ibn Yahya al-Zuhlya, Abya Hatim al-Razy, Muhammad ibn 'Abd al-Rahim Sa'qah, 'Abd ibn Humaid, Ahmad ibn al-Nadar, and others.

Fifth, a number of people from the age and sanad aspects were the same as al-
Bukhary. He heard or narrated from them to streng then the hadith. They were 'Abd Allah ibn Hammad al-Amily, 'Abd Allah ibn Aby al-'As al-Khawarizmy, Husen ibn Muhammad al-Qabbany and others. ${ }^{38}$ 


\section{Teachers of al-Bukhary}

The First Tabaqat

The teacher who narrated the Hadith from Tabi'in

\section{The Second Tabaqat}

The teacher who did not narrate the Hadith from Tabis $n$

The Third Tabaqat
Those who had not met Tabi'in,
bur narrated the hadith from the Great Tabicit at-Tabici

The forth Tabaqat

Al-Bukhary friends who were more senior in studying and gathering Hadith

\section{The Fifth Tabaqat}

Friends of al-Bukhary's age in

Studying and Gathering Hadith

The following is the summarize of the many teachers and students of al-Bukharya. Some prominent teachers and students such as Abu Shuhbah dan Muhib al-Din alKhatib $^{39}$ is mentioned as follows:

Teachers and Students of al-Bukhary

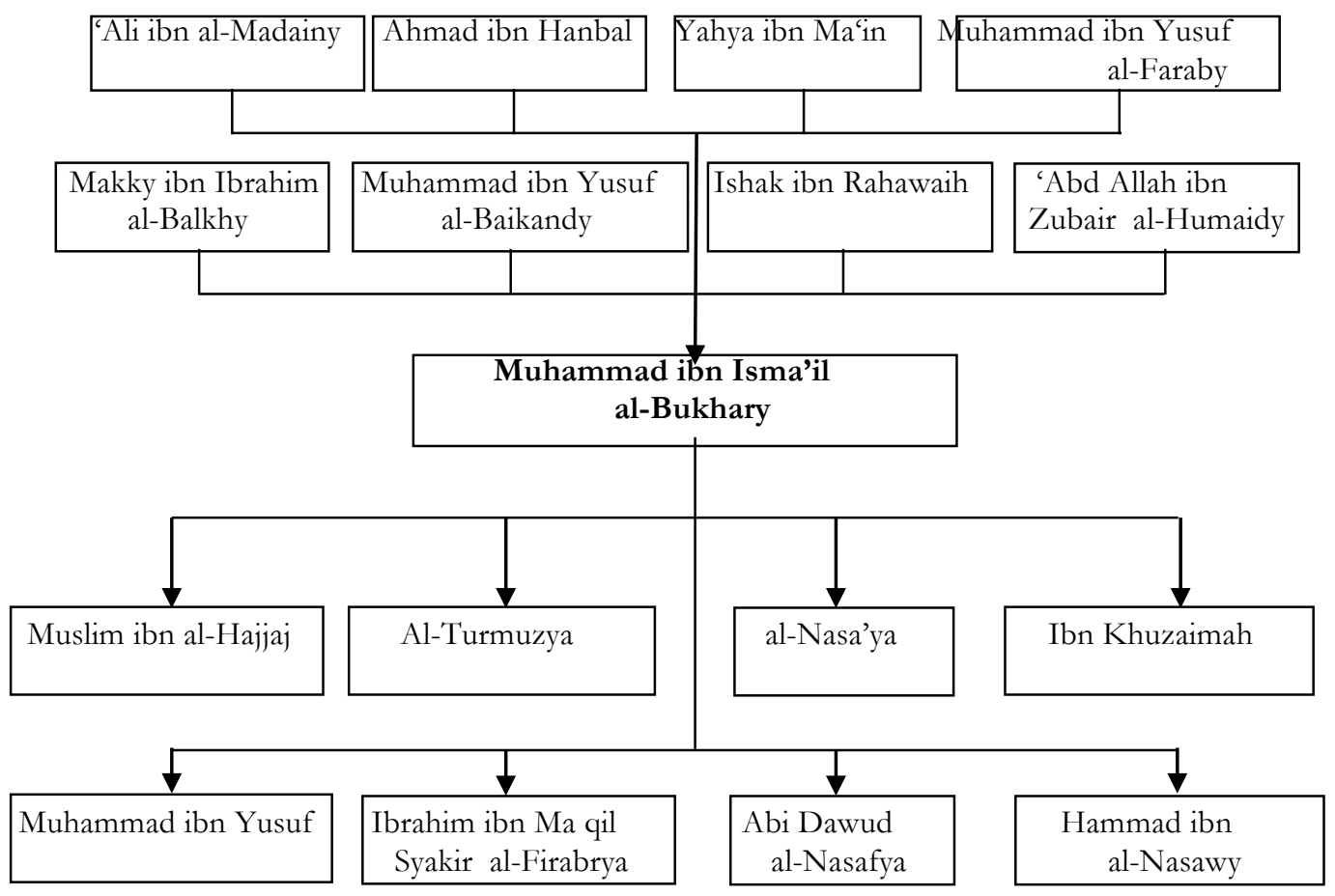

${ }^{39}$ Abua Shuhbah, Fya Rihab al-Sunnah, pp. 49-50. 
The widespread journey of al-Bukhary was an attempt to look for science and to gather the hadiths of the Prophet. He had outlined new steps for future generations since the previous generation was only collecting the hadiths of the Prophet in their respective cities of residence. For example, Ibn Ishaq (w.156 H) and Malik ibn Anas (w. 179 H) compiled the hadiths in Medina while Ibn Juraij (w.150 $\mathrm{H})$ collected the hadiths of the Prophet in Mecca and others. There was only a small number of ulamas who gathered from other cities. Al-Bukhary was the first person to expand the knowledge to almost reach all Islamic jurisdictions.

\section{Al-Bukhary Authority as Expert of Hadith and Fiqh}

An ulama can be said to be a follower of a particular school of law when he studied directly with the founding imam of the school or indirectly with the students or friends of the founding imam of the school. Intellectul inheritance about certain disciplines almost always gives birth to figures influenced by the views of the teacher of the discipline. Al-Bukhary awas in contrast. He lived in the time of Shafici school of law got a place among the people who lived in two centers of science (Hijaz and Kufa) and the surrounding areas such as Bagdad, Egypt, Syri, and Yemen.

Al-Bukhary had never studied directly with al-Shafici because when alSyafi'I died (204/819), al-Bukhary was still relatively young $( \pm 10$ years old). Moreover, he still lived in Bukhara while al-Shafici resided in Egypt for around 6 years before his death. Therefore, they never met physically. At the age of 16 , alBukhary lived in Mecca. ${ }^{40}$ There, he learned from several ulamas who were students of al-Shafici, such as al-Humaidy and others. The expertise of al-Bukhary in fiqh was obtained from al-Humaidy, a friend and student of al-Shafici. He was a popular Fakih who became a mufti in Mecca. ${ }^{41}$

Al-Bukhary awas considered alShafi'y follower because he had studied with students of al-Shaficy. In addition, Shafici school of law is seen as a moderate school because it is between the two

\footnotetext{
40 There were two centers of Islamic science at that time, Hejaz (Mecca and Medina) known as the Expert School of Hadith and Iraq (Kufah and Basrah) known as the school of $A b l \mathrm{R}^{6} \mathrm{y}$.

${ }^{41}$ Muhib al-Din al-Khatib, al-Ta'rif, p. 11.
} 
extremes school of thought an extreme oriented stream of texts (hadith) and ra'yu (reasoning). Al-Shafi' $y$ succeeded in synthesizing two basic systems of Islamic law in the Kufa school of law which adhered to qiyas (analogy) which rejected hadith (text). On the contrary, hadithbased Hijaz school of law rejected qiyas. Al-Shafi'y amade both of them a basic system of Islamic law in its school of law by giving a new interpretation to both. ${ }^{42}$ Due to the acceptance of alShafi'ya interpretation, each school of law had undergone a process of adaptation.

The description above is sufficient as an argument to classify al-Bukhary as a follower of Shafici due to the intellectul genetics and environment. Moreover, alBukhary was mentioned in the book of Tabaqat al-Shafi'iyyah al-Kubra as a follower of Shafi'ya. This means there is indirect recognition. Therefore, the grouping of alBukhary ainto Shafi'ya because it fulfills two double criteri namely intellectul genetics and recognition.
However, Ahmad Amin doubted the validity of the statement above. Amin said that al-Bukharya syara' mujtahid. ${ }^{43} \mathrm{Al}-$ Bukhary had his own method of istinbat law. His legal thoughts sometimes correspond to Hanafy and Shafi'y school of law. However, sometimes his thoughts also infrequently different from the two. At one time, he chose the school of the companion (sahabah) such as Ibn 'Abbas, Mujahid, 'Ata' and other schools of law. For example, people who are Junub may read Qur'an. Sick people who are afraid to use cold water may pray using tayammum. Praying with sandals is acceptable. The trading provisions were set in the urf. It is acceptable to teach Qur'an to the scribes and others This proves that al-Bukhary was not bound by any schoolsof law. ${ }^{44}$ Similar statement made by $\mathrm{Abu}$ Shuhbah. ${ }^{45}$ He also added that al-Bukhary was not a muqallid (follower of the school of law). ${ }^{46}$ According to his study, the arjab al-Bukhary was a Tabaqat mujtahid Mustaqil (independent in istinbat method and Islamic law reasoning), and not bound by any school.

\footnotetext{
42 The latest interpretations were made by alShafi'ya. Hadith is everything said by the Prophet Muhammad with a valid transmission, not an expert tradition of Medina as the initil meaning held by Malikya. Meanwhile, analogy or qiyas is equating a case that does not have the law in nas, because of the equality of illat law. On the contrary, the meaning of qiyas held by followers of Hanafy was free thinking.
}

\footnotetext{
43،Abd al-Wahhab Khallaf, Imu Usual al-Fiqh, p. 95. ${ }^{44}$ Ahmad Amin, Duba al-Islam, juz II, p.114. See also

${ }^{45}$ Abua Shuhbah, Fy Rihab al-Sunnah, pp. 64-65.

${ }^{46}$ In usual term, muqallid is the lowest level of the school of law that follows the opinion or fatwa of a school of law without knowing its legal basis.
} 
Hamlainy 'Abd Majid Hashim ${ }^{47}$

rejected the assumptions that classify alBukhary as a follower of a certain school of law. He argued that al-Bukhary was an absolute mujtabid. The followers of the four Sunny schools of law scrambled to relate al-Bukhary with their respective schools of law. Al-Subky, a prominent ulama of Shafi'y claimed al-Bukharay as a follower of Shaf'y, because he had been a student of the students and friends of alShafi'y such as al-Za'farany, Abu Saur, alKarabisy and al-Humaidy. Ibn Aby Ya'la classified al-Bukhary for a follower of Hanbaly school of law because he had been a student of Ahmad ibn Hanbal. Malikiyah ulamas claimed al-Bukhary as a follower of Maliki because he narrated alMunvatta 'by Imam Malik through 'Abd Allah ibn Yusuf al-Tanisya, Sacid ibn 'Anbar and Ibn Bukair. Hanafiyah ulamas also claimed al-Bukhary as a follower of the Hanafi school of law because he had studied with Ishaq ibn Rahawaih, a follower of Hanafy. Ishaq was al-Bukhary ateacher who was the most influentil person in the compilation of al-Jami alSabih.

${ }^{47}$ Hamlainy'Abd al-Majid Hashim, al-Imam alBukhary Mubaddisan wa Faqihan, (Egypt: Dar alQaumiyyah li al-Tiba'ah wa al-Nashr, t.th.), pp.169-173.
If a student has to follow his teacher's school of law and cannot be a mujtahid himself, then there will be no mujtahid because ulamas of the four school of law were also a follower of the previous school of law. In fact, Imam alShafi'y ahad been a disciple of Imam Malik and memorized the book of Muwatta' by Imam Malik. Al-Shafi'ya had also studied hadith from Ahmad ibn Hanbal. Imam Malik learned figh from Rabi'ah al-Ra'y. Rabi'ah had studied fiqh from Abu Hanifah, and Abu Hanifah had studied with Ibrahim an-Nakha'ya. However, they can be an absolute mujtahid and not a follower of their teachers' school of law.

They were prominent mujtahid who studied with some of the previous ulamas. They had their own jurisdiction. Their ijtihad products corresponded to the Qur'an, Hadiths, asar, and the opinion of Sahabah (Prophet's companions) and tabiin. Their ijtihad products also correspond to ijma' and qiyas. From those ulamas, brillint fiqh ideas for the formation of Islamic law were spread. Likewise, al-Bukharymemorized Qur'an, al-Sunnah, asar and the opinion of Sahabah (Prophet's companions) and tabiin. He had a broad knowledge of fiqh. He can explore the thoughts of fiqh 
because of his extensive and profound mastery of hadith.

\section{Al-Kashmiry, ${ }^{48}$ a review of al-Jami ${ }^{6}$} al-Sabih, said that there was no doubt that al-Bukharywas a mujtahid. He was known as a follower of Shafi'ya because some of this thought on popular problems correspond to al-Shafi'ya such as the problem of having to read al-Fatihah, raising both hands in prayer, and pronouncing 'amin recitation for ma'mum (follower of congregational prayer). In addition, he was a student of al-Humaidy, Shafi'y follower. Thus, al-Bukhary was known as a follower of Hanafy because his opinions are much in line with Hanafy school of law. Besides, he was a student of Ishaq ibn Rahawaih, a follower of Hanafy. Ishaq was one of the leading disciples of Ibn al-Mubarak, one of the leading disciples of Imam Hanafy. Meanwhile, Imam Muslim was unknown to his school of law, al-Turmuzy and Ibn Majah were the followers of Shafi'y school of law.Al-Nasa'y and Abu Dawud was better known as a follower of Shafi'y, but actully both of them were the follower of Hanbaly.

48 Muhammad Anur Shah al-Kashmiry, "al-'Urf alShazy Sharh Sunan al-Tirmuzy volume I, alMaktabah al-Shamilah, edition II. Majmua'ah XIV, Number 12, p. 9.
From the description above, it can be seen that the assumption that alBukhary ais Mujtahid fy al-Mazhab is incorrect. Al-Bukhary was not affected by any school of law. He had his own methodology like the imam of other schools of law. Al-Bukhary cannot be associted with a particular school because his legal thinking revolves around the meaning of hadith. Therefore, his legal thinking can be in accordance with or different from other schools of law.

There are many statement which more inclined to praise the virtues of alBukhary amade by ulama, including: Hashid ibn Isma'il once told that when alBukhary visited Basrah Muhammad ibn Bashar (w. $252 \mathrm{H}$ ), a prominent ulama in Basrah said: "Has come today Sayyid alFuqaha'”. On another occasion he also said: "Al-Bukhary is the most devout creature of God in our time" (buwa afqahu al-khalq fy ramanina). Ya'qub ibn Ibrahim al-Dauraqy and $\mathrm{Na}$ 'im ibn Muhammad alDauraqy similarly said, "Muhammad ibn Isma'il Faqib hazibi al-ummab" (Muhammad ibn Isma'il or al-Bukhary ais today's jurist of the people). ${ }^{49}$

In contrast to the ulamas mentioned above, Ahmad Amin gave a statement, reasons, and evidence about al-

${ }^{49}$ Al-Subky, Tabaqat, juz II, p. 9 
Bukhary expertise. In his opinion, alBukhary expertise in fiqh was due to his expertise in hadith. ${ }^{50}$ The long and tiring journey carried out by him in gathering hadith led him into expertise in fiqh. A set of knowledge's needed as the condition for making ijtihad had such as ilmu alQur'anilmu al-Hadis, ilmu Usul al-Figh and others had been mastered by him.

Al-Bukharyexpertise in figh has been forgotten by many people. Western scholars such as Joseph Schacht, Noel J. Coulson, J.N.D. Anderson, and Wael B. Hallaq as well as contemporary scholars ignored his fiqh thoughts. ${ }^{51}$ Even Ibn Abya Ya'la in Tabaqat al-Hanabilah mentioned Muhammad ibn Ismail alBukhary as the ulama of Hanbalya. ${ }^{52}$ This grouping was made because alBukharylived contemporary with Imam Ahmad ibn Hanbal and narrated several hadiths from him. Some of the other

\footnotetext{
${ }^{50}$ Ahmad Amin, Duba al-Islam, juz II, p.114.

51 Scott C. Lucas mentioned that only Ignaz Goldziher who boldly mentioned al-Bukharya attitude towards qiyas (al-Bukhary's expertise in usual al-Fiqh) even though Historins, al-Khatib alBagdady and Shamsuddin al-Zahabya, included him in their respective books (Tarikh Madinah alSalam and Siyar al-Alam al-Nubala) as a contemporary ulama specilized in Islamic law (Fiqh). He was mujtahid fiqh tho had critical thoughts in Islamic legal philosophy (ushul figh). Scott C. Lucas, "The Legal Principle of Muhammad ibn Ismacil al-Bukharya and Their Relationship to Classical Salafy Islam", in Journal of Islamic Law and Society, pp. 13,3 (Leiden: Koninklijke Brill NV, 2006), p.292.

52 Ibn Aby Ya'la, Tabaqat al-Hanabilah, pp.106-110.
}

ulama classified al-Bukhary into Shafi'ya school of law. Moreover, Taqya al-Din alSubkya classified him into ulama of Shafi'ya in the book entitled Tabaqat alShafi iyyah al-Kubra. This grouping is understandable because al-Bukharystudied with students and friends of al-Shafi'ya such as al-Humaidya (w. $219 \mathrm{H}$ ), Husain (w. $248 \mathrm{H}$ ), Abu S|aur (w. $246 \mathrm{H}$ ) and others when he lived in Hijaz.

\section{Closing}

From the above description, it can be concluded that al-Bukhary is an Islamic intellectul figure who has an extraordinary life journey. He carried out ribla in order to codify hadiths from various regions such as Bukhara, Hijaz, Damascus, and Egypt. During his journey, he met many teachers who had high scientific qulity.Among his teachers were 'Aly ibn al-Madainy (w. 234/848), Ahmad ibn Hanbal (w. 241/855), Yahya ibn Macin (w. 233/847) Muhammad ibn Yusuf alBaikindy (w. $218 \mathrm{H}$ ) and Ishaq ibn Rahawaih (w. 237 H). However, alBukhary was not spared from slander. Thus, most of his followers left his majlis ta'lim. This slander arose from the accusation that al-Bukhary was a follower of the opinion that Qur'an was a creature. The political dynamics in al-Bukharyera 
also influenced his authority as the leading ulama of his time.

The Central Asin intellectul tradition also influenced al-Bukhary in carrying out ribla (scientific research or journey) into various Islamic regions. The scientific journey carried out by alBukhary to various regions to learn from leading scholars in the era and to collect hadiths made him an expert in hadith and figh at once. The results of reading a number of hadiths gave birth to new ijtihad that was different from the predecessor of al-Bukhary predecessor. Therefore, many people classified alBukhary as a mujtahid. In fact, Hamlainy 'Abd Majid Hashim argued that alBukhary was an absolute mujtahid.

\section{REFERENCES}

Ahmed, Munir al-Din, Muslim Education in The Scholars Socil Status. Zurich: Verlag Der Islam, 1968.

Akiner, Shirin, "Islam, the State and Ethnicity in Central Asi in Historical Perspective," Journal of Religion, State \& Society, Vol. 24, No. 2/3 .1996.

Amin, Ahmad, Dhuba al- Islam Cairo: Maktabah al-Nahdah al-Misriyyah, 1974.

'Asqalany al-, Ahmad ibn 'Alya ibn Hajara, Hady al-Sary, Egypt: Daral-Diyan li al-Turas, 1988.

Fath al-Barya, volume I . Cairo:

Dar al-Diyan li al-Turas, 1988.
Bagdady al-, Ahmad Ibn 'Alya al-Khatib, Tarikh Bagdad aw Madinah al-Salam, volume II . Cairo: al-Khaniji, 1931.

Dogde, Bayard, Muslim Education in Medieval Times. Washington D.C.: The Middle East Institute, 1962.

Hashim, Hamlainy'Abd al-Majid, al-Imam al-Bukhary Mubaddisin wa Faqihan, Egypt: Dar al-Qaumiyyah li alTiba'ah wa al-Nashr, t.th.

Jabiry al-, Muhammad 'Abid a, alMusaqqafunaa fya al-Hadarah al'Arabiyyah: Mibnab Ibn Hanbal wa Nakbah Ibn Rusyd (Tragedi Intelektul: Perselingkuhan Politik dan Agama), Zamzam Afandi 'Abd Allaha, Trans.Yokyakarta: LKiS, 2003.

Kashmiry al-, Muhammad Anur Shah a, "al-'Urf al-Shazi Sharh Sunan alTurmuzi " avolume I, al-Maktabah al-Shamilah, edition II. Collection XIV, Number 12.

Lucas, Scott C, "The Legal Principle of Muhammad ibn Isma'il alBukharyand Their Relationship to Classical Salafi Islam", in Journal of Islamic Law and Society 13, 3 Leiden: Koninklijke Brill NV, 2006.

Nakosteen, Mehdi, History of Islamic origins of Western education. A.D. 800-1350 with Introduction to Medieval Muslim Education (Boulder: University of Colorado press, 1964.

Syalabi, Ahmad, Sejarab dan Kebudayan Islam, volume III .Jakarta: Pustaka al-Husna, 1993.

Shuhbah, Muhammad Muhammad Abu, Fya Ribab al-Sunnab, Ala kutub alSittah al-Sibhah, Cairo: Majma' alBuhus \al-Islamiyyah, 1969. 
Shuhbah,Taqiy al-Din Abya Bakr ibn Ahmad ibn Qadya, Tabaqat alFuqaha al-Shafi'iyah, . Cairo: Maktabah al-S $\mid$ aqafah al-Diniyyah, t.th.

Suyutya al-, Jalal al-din, Tarikh al-Khulafa' . Beirut: Dar al-Fikr, 1974.

Subky al-, 'Abd al-Wahhab ibn Taqya alDin a, Tabaqat al-Shafi'iyyah al-
Kubra, Juz II. Egypt: al-Hasiniyyah al-Misriyyah, t.th.

Ya`a, Ibn Abya, Tabaqat al-Hanabilah, AlMaktabah al-Shamilah, Edition II, Collection Number 46 